\title{
Error Analysis of Simple Present in Writing Descriptive Text
}

\author{
Indah Lestari \\ indahlestarii2199@gmail.com \\ English Education Program, Universitas PGRI Yogyakarta
}

\begin{abstract}
The purpose of this study was to determine the extent to which the ability to write $4^{\text {th }}$ - semester students in the English Education Program at PGRI University of Yogyakarta. Researcher specifically examined the use of Simple Present Tense in a descriptive text. Researcher using Surface Strategy Taxonomy. The researcher also used a qualitative descriptive method to check what errors they made and how often they were frequent. The steps the researcher took were giving students 3 themes, namely Family, My Idol \& Beautiful Place in Yogyakarta. After that students choose one theme and then write a descriptive text. The results of this study indicate that students made 33 errors (47.14\%) from 70 Present Present Tense sentences. This was less than the correct use of Simple Present Tense, with a total of 37 (52.86\%). Students made the most error in misformation by 13 (39.39\%). Whereas the most rarely made error is addition with a total of $2(6.07 \%)$.
\end{abstract}

Keywords: Error analysis, Simple Present Tense, Descriptive text

\section{INTRODUCTION}

As we know, English is a language that is recognized as a universal language in the world. In fact, according to (Zawahreh, 2012) to find out what is happening to the world such as the economy, politics, and technological development, we must understand and learn English. In learning English, we must understand the four basic skills; listening, reading, speaking and writing. Writing is one of the most important skills that must be learned by students, used to provide factual, persuasive and entertaining information by expressing ideas, opinions that are arranged systematically and following certain rules.

According to Harris and Cunningham (1994), writing is the most difficult skill because it takes a deep understanding of what will be written, the use of appropriate vocabulary, grammar that is acceptable to the reader. Even to write a good paragraph, it takes a lot of books and references that must be read and used as references. And in the 
end, writing cannot be learned autodidactly, so to produce a good and acceptable writing, writing expertise requires a process that is not easy, time is not short and requires continued practice.

In writing, students can never be separated from grammar. What is grammar? According to Richards and Schmidt (2010) grammar is a rule that specifically regulates how words and phrases are formed into a sentence. Another definition according to linguist, Chomsky (1986) grammar is the limitations that make us able to produce a sentence that is correct so that it can be understood by the listener and reader.

Grammar is difficult to learn by foreign language learners because each language has its own grammar rules. For example between Indonesian and English which have quite different grammar, in Indonesian it does not really regulate how verbs should be used. But in English there are many rules that must be considered, especially in the use of tenses, which are rules that indicate activities within a certain time. One such tense is simple present tense. Simple present tense is used when talking about general truths and permanent situations (Raymond Murphy: 2003). In line with this definition, Betty (2002) explains that simple present is used to show something that always happens, in the past, present and future.

Making errors is basically a human process when learning. So it is very possible to happen to foreign language learners. This is as expressed by James (1998) that error analysis is the process of determining the reason for language failure. Pateda (1989) said that analysis error is very useful for teachers in particular in order to find out what errors are most often done by learners, improve the system and learning methods.

The previous research done by Ratna, Patuan, Budi (2013) showed that from the results of their research, students use simple present tense more correctly with a percentage of $73.81 \%$. Compared to previous studies, research by Siti Himmatul (2017) showed that students still made many errors when using simple present tense on descriptive text. Those errors lie in misordering as much as $34 \%$ with the reason being that students not familiar with English grammar caused by differences in grammar rules between Indonesian and English. This is reinforced by research from Uswatun (2017) which said that students still made errors with a percentage of $50 \%$ on omission errors which are again caused by the dominance of Indonesian in their daily grammar.

Errors in writing descriptive text can occur at any level of education. But in this study, the researcher focused on analyzing third-semester students who specifically 
majored in English Education. This study investigates what errors most frequently occur in using simple present tense in descriptive text. It is hoped that after learning these mistakes, do not repeat the same errors and can correct them.

\section{RESEARCH METHOD}

This research was designed as a descriptive qualitative method. Qualitative methods are considered appropriate to explain data in the form of text obtained from respondents in detail. As explained by Moleong in Aryo (2017) that qualitative research is research that aims to understand what phenomena experienced by research subjects such as motivation, action, perception and others by means of descriptions in the form of words in a particular context and method natural. In this case, the researchers used a taxonomy surface strategy to analyze grammatical errors, especially simple present in descriptive text.

The object of this research is descriptive text made by the $4^{\text {th }}$-semester students of Yogyakarta PGRI University. In one class studied there were 8 students. In addition, research instruments are also needed which finally written descriptive text written by students is chosen by researchers to be an instrument in this study. Researchers also provide 3 themes so students are not confused and make it easier for them to write. The themes are "Family", "Beautiful Place in Yogyakarta" and "My Idol".

The first step the researcher did was to ask all students to write descriptive text by choosing one of the predetermined themes. The next step is to analyze the data by recognizing which sentences use simple present correctly and also looking for which sentences have errors. After obtaining an error sentence data, the researcher classifies the type of error again using a surface strategy taxonomy. Whether the error is included in omission, addition, misformation, or misordering. Researcher also calculates the frequency of each error that occurs. To calculate what percentage of the number of errors that occur, researchers use the percentage formula as follows:

$\mathrm{P}=\frac{n 1}{\sum^{N}} \times 100 \%$

$\mathrm{P}$ : Percentage of each error

$\mathrm{n} 1$ : Total of the given error

$\sum \mathrm{N}$ : Total of the whole error 


\section{RESULTS AND ANALYSIS}

This research was actually completed on the 10th April 2020 from 8 4th semester students of PGRI Yogyakarta University. The results of the study are listed in the table below:

Table 1. Results of the study

\begin{tabular}{|l|l|l|l|}
\hline Total of Students & $\begin{array}{l}\text { Total Simple } \\
\text { Present Tense }\end{array}$ & $\begin{array}{l}\text { The Correct Use of } \\
\text { Simple Present Tense }\end{array}$ & $\begin{array}{l}\text { Total Errors in Using } \\
\text { Simple Present Tense }\end{array}$ \\
\hline 8 & 70 & 37 & 33 \\
\hline \multicolumn{2}{|r|}{ Percentage } & $52,86 \%$ & $47,14 \%$ \\
\hline
\end{tabular}

The results above indicate that students have understood simple present tense with a total of $52.86 \%$. The most visible is that students have correctly placed the use of -s or es in sentences depending on the subject. As in the sentence: Although she is very busy at work, she never forgets her family. She is good at cooking. She always serves food for breakfast before I go to campus.

But the result is only $5.72 \%$ difference or 4 sentences error, so it cannot be said that students really understand Simple Present with a very good level. From a total of 70 Simple Present Tense, students still make as many as 33 sentences in their writing. Below clearly explained their error which has been classified according to surface strategy taxonomy:

Table 2. Type of Error

\begin{tabular}{|l|l|c|c|}
\hline No & \multicolumn{1}{|c|}{ Type of Error } & Total Errors & Percentage (\%) \\
\hline 1 & Omission & 11 & $33,33 \%$ \\
\hline 2 & Addition & 2 & $6,07 \%$ \\
\hline 3 & Misformation & 13 & $39,39 \%$ \\
\hline 4 & Misordering & 7 & $21,21 \%$ \\
\hline \multicolumn{2}{|l|}{ Total } & 33 & $100 \%$ \\
\hline
\end{tabular}

Based on these results it can be seen that the most errors were in misformation of 13 errors (39.39\%). Misformation is an error where the use of morpheme or structure is wrong. The most error made by students in using to be, how should is and are used 
depends on singular or plural. Like when explaining something to someone's body. For example: His skin are white.

Next is omission. Omission became the second most error after misformation with $33.33 \%$. Omission is an error that occurs due to loss of items in a form that is really needed in well-formed. This error is most clearly seen when students omit articles such as a / an and the in a sentence they write. For example: He is employee in company. or My mother is patient woman, she is the best chef ever.

With $21.21 \%$, misordering becomes the third error that is often done by students. Misordering is an incorrect morpheme placement because of the confusion that occurs when composing sentences because students are still affected by the sentence structure in Indonesian. For example: She has hair black.

Finally, the least errors made by students are addition. Addition is the addition of an item that is not needed in well-formed writing. This was only done twice by two different students with a total percentage of $6.07 \%$. For example: My best partners in the world first is my father. For this reason, it is certain to add that almost all students understand well.

\section{CONCLUSION}

Based on the result and discussion it can be concluded that students in using the correct simple present when writing descriptive text reached $52.86 \%$. Only a small difference in the total error they do is $47.14 \%$. Although the true percentage is greater, only a little different from the percentage they make an error. This indicates that students have not reached the level that is said to be very good.

The most frequent error they do based on the surface strategy taxonomy is in misformation with a percentage of $39.39 \%$. The error made by these students were mostly on to be, how they have to adjust plural or singular. Whereas the fewest error is addition. They rarely made these error, so the percentage error was only at $6.07 \%$. 


\section{REFERENCES}

Abdullah, A. (2013). Error Analysis on The Use of The SimpleTense and The Simple Past Tense in Writing Essays Among TESL College Students. International Journal of Education and Research, 1(12), 1-12.

Azar, Betty Schrampfer. (2002). Understanding and Using English Grammar Third Edition. New York: Longman.

Bialystok, E., Dulay, H., Burt, M., \& Krashen, S. (1983). Language Two. In The Modern Language. Journal (Vol. 67, Issue 3, p. 273). https://doi.org/10.2307/327086

Chomsky, Noam. (1986). Knowledge of Language: Its Nature, Origin and Use. Westport, CT: Praeger.

Dulay, H., Burt, Krashen. (1982). Language Two. New York: Oxford University Press.

Harris, G, J., and Cunningham, H.D. (1994). The Simon and Schuster Guide to Writing. New Jersey: Prentice Hall, Englewood Cliffs.

Haryadi, T., \& Putra, A. (2018). An Analysis of Students' Errors in Writing Narrative Text: A Case Study at the Eleventh Grade of Sma Muhammadiyah Mataram. Academic English Education Program Language and Arts Department Faculty of Teacher Training and Education Mataram University 2018.

Hasanah, U. (2017). Error Analysis on Using Simple Present Tense in Writing Descriptive Text Made by The Tenth Grade Students of SMA N 1 Pace in Academic Year 2015/2016 (Skripsi). Kediri (ID): University of Nusantara Kediri.

Jayanti, A. (2019). Students' Writing Ability on English Descriptive Text at Grade VIII in SMP 33 Padang. Academic Journal of English Language and Education. 3(1). 7194.

Juwitasari, R. Patuan Raja., \& Budi Kadaryanto. (2012). An Analysis of Grammatical Errors in Using Simple Present Tense in Descriptive Text Writing By Students of Man 1 (Model) Bandar Lampung. FKIP Universitas Lampung, 1, 1-13.

Mahe, F. (2014). Error Analysis of Written English Paragraphs by Jordanian Undergraduate Students: A Case Study. International Journal of English Language, Literature and Humanities, II (VIII), 85-100.

Murphy, Raymond. (2003). English Grammar in Use. New York: Cambridge University Press.

Pateda, Mansoer. (1989). Analisis Kesalahan. Ende Plores: Nusa Indah.

Richard, J.C. and Schmidt, R. (2010). Longman Dictionary of Language Teaching and Applied Linguistics Fourth Edition. Great Britain: Pearson Education Limited. 
Setyaji, A., Sukmaningrum, R., \& Hawa, F. (2017). Analisis Kesalahan Gramatikal pada Penulisan Descriptive Text Mahasiswa Jurusan Pendidikan Bahasa Inggris Universitas Semarang. 11(2), 37-58.

Suhono, S. (2017). Surface Strategy Taxonomy on the Efl Students' Composition a Study of Error Analysis. Jurnal Iqra', 1(2), 1. https://doi.org/10.25217/ji.v1i2.128

Vera, B., Haryudin, A., \& Herdiyanti, W. (2019). Error Analysis on the Students Writing of Simple Present Tense in a Descriptive Text. PROJECT (Professional Journal of English Education), 2(4), 514. https://doi.org/10.22460/project.v2i4.p514-520

Zawahreh, F. (2012). Applied Error Analysis of Written Production of English Essays of Tenth Grade Students in Ajloun Schools, Jordan. International Journal of Learning and Development. 2(2), 16-35.

\section{BIOGRAPHIES OF AUTHORS}

I am Indah Lestari currently active as an English Education student at PGRI University of Yogyakarta. I was born in Kebumen 21 years ago and then the journey took me to sit in the $4^{\text {th }}$ semester at the moment. 